Vol. 1 No. 2

September 2018

202

Received: August 27, 2018 Revised:September 24,2018 Accepted: October 22, 2018

\section{Government Cooperation}

(Study of the Cooperation between

the Central and Regional

Governments in the Development

of Tourism Priority Destinations in

Tanjung Kelayang, Bangka Belitung)

\author{
BERTHI RAMADHANI $\mathrm{P}^{1}$, TRY SULISTYANINGSIH ${ }^{2}$, \\ KHRISNO HADI ${ }^{3}$ \\ Universitas Muhammadiyah Malang \\ berthi723.key@gmail.com, sulis226@gmail.com, \\ krishnohadi@gmail.com
}

\begin{abstract}
In order to improve and develop the priority sector in term of the tourism sector, there are ten priority destinations, in Indonesia, determined under Joko Widodo's administration, one of which is in Tanjung Kelayang, Bangka Belitung. This is being the domain of authority on both the central and regional governments as it is necessary for government cooperation. The results of the study found that the model of cooperation between the central and regional governments in the program has consisted of development through government cooperation, not only based on the KSPN, but also the KEK in the concept of ABCGM. In fact, for each model of the cooperation's implementation, there are still some undeniable problems. First, the local government is less able to take advantage of the opportunities in proposing activities to the central government through the Deconcentration Fund and DAK in the KSPN status. Second, there are some activities, which are unfocused and unsuitable for the development of KEK's Tanjung Kelayang. In the one side, there are several inhibiting and supporting factors identified as well as influencing the government cooperation in the development of Tanjung Kelayang. Priority Destinations focus on accessibility in such transportation, awareness of community tourism, community creativity while supporting factors are many foreign tourists. Moreover, there are famous tourist attractions namely "Laskar Pelangi Island". Thus, the central and regional government cooperation can conclude that it is
\end{abstract}


still not enough efforts to develop the Tanjung Kelayang's destination as a priority destination in Indonesia.

Keywords: Government cooperation; tourism development; priority

\section{ABSTRAK}

Untuk meningkatkan dan mengembangkan sektor pariwisata di Indonesia, Pemerintahan Joko Widodo menentukan 10 destinasi yang menjadi prioritas, salah satunya di Tanjung Kelayang, Bangka Belitung. Daerah ini telah menjadi prioritas baik pemerintah pusat maupun daerah dan diperlukan kerja sama antara keduanya. Sesuai dengan hasil penelitian, model kerjasama antara pemerintah pusat dan daerah dalam program tersebut terdiri dari pengembangan melalui kerjasama pemerintah, tidak hanya berdasarkan KSPN, tetapi juga KEK dalam konsep ABCGM. Bahkan, untuk setiap model implementasi kerjasama, masih ada beberapa masalah yang tidak dapat disangkal. Pertama, pemerintah daerah kurang mampu memanfaatkan peluang dalam mengajukan kegiatan kepada pemerintah pusat melalui Dana Dekonsentrasi dan DAK dalam status KSPN. Kedua, ada beberapa kegiatan, yang tidak terfokus dan tidak sesuai untuk pengembangan Tanjung Kelayang di KEK. Di sisi lain, ada beberapa faktor penghambat dan pendukung yang diidentifikasi dan mempengaruhi kerjasama pemerintah dalam pembangunan Tanjung Kelayang. Destinasi prioritas fokus pada aksesibilitas seperti transportasi, kesadaran pariwisata masyarakat, kreativitas masyarakat, sementara faktor pendukungnya banyak wisatawan asing. Selain itu, terdapat tempat wisata terkenal yaitu "Pulau Laskar Pelangi". Dengan demikian, kerjasama pemerintah pusat dan daerah dapat disimpulkan upaya yang masih kecil untuk mengembangkan destinasi Tanjung Kelayang sebagai destinasi prioritas di Indonesia.

Kata Kunci: Kerjasama Pemerintah; Pembangunan Parawisata; Destinasi Prioritas.

\section{INTRODUCTION}

Indonesia as a unitary state distributes power based on the relationship between the central and regional governments linked to a decentralized system and a centralized system, (Saiman et al., 2017). As a country with a decentralized system, decentralization does not intend to break the relationship between the central government and regional governments, but instead with decentralization it will allow the opening of cooperative relations between government units. Government administration is regulated in law number 23 of year 2014 concerning regional government. According to Laksono, Topatimasang and Permana, decentralization is the process by which the government transfers the authority in the form of politics, fiscal, and administrative authority to the regional government, (Antwi-Boasiako, 2010). 
Vol. 1 No. 2 September 2018

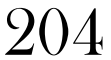

There are several government affairs in the administration of government, one of which is tourism affairs that are concurrent affairs, divided between the central and provincial governments and district/city regions in law number 23 of year 2014 regarding regional governments. In the era of Joko Widodo leadership, tourism is one of the priority sectors in addition to Food, Maritime, Energy and Industrial Estates. Tourism is considered as the cheapest and easiest contributor to GDP, foreign exchange and employment.

The problem of tourism in Indonesia is that tourism development is only concentrated in the Java-Bali region so that tourism development is not evenly distributed, weak tourism planning and Indonesia only relying on one gate of foreign tourists in Bali, (Nirwandar, 2007). Indonesia, which only relies on one gate of foreign tourists, is not surprising that foreign tourists who travel very little and unstable growth. Besides that, starting from 2013 to 2015 , tourism is in a stagnant area or remains that the tourism sector is the 4th foreign exchange contributor (Ramadhani, Sulistyaningsih, \& Hadi, 2018).

In the meeting of Tourism between Deputy of Destination and Tourism Industry Development, Ministry of Tourism, with West Kalimantan DPRD (regional legislatures) regarding RIPPARDA (Master Plan for Regional Tourism Development), on 11 October 2017, Deputy Secretariat of Tourism Destination and Industry Development, said that "the parameter of tourism is foreign tourists". Thus, tourism will never exist if no one travels out of the usual neighborhood for a while and visits another place, (Antariksa, 2015). The central and regional governments should be able to encourage and support long- term programs in the form of other major gateways for Indo- nesian tourism, (Nirwandar, 2007).

In 2016, President Jokowi gave 8 directives on the topic: "in 2016 is the Year of Acceleration" as stated in the Secretariat Letter No: B-652/Seskab/Maritim/11/2015, on November 
6,2015 . This is one of these directives that is to ensure progress in the field at 10 national tourist destinations. The central government through the Ministry of Tourism calls the national tourist destination "10 New Bali", (Ratman, 1976). The national spots were chosen by the ministry of economy in the maritime and resources sector to become ten priority tourism destinations as stated in the Letter of the Coordinating Minister for Maritime and Resources: No. S54/Menko/Maritim/VI/2016 on 29 June 2016, (Moerwanto, 2017). One of the project is Tanjung Kelayang in Bangka Belitung.

For the tourism sector, the Ministry of Tourism provides a support related to deconcentration and co-administration activities to accelerate the development of tourism in the region, especially tourism in the KSPN (National Tourism Strategic Area) status, (Kristiana, McDonald, Tan, Joll, \& Heitz, 2015). Tanjung Kelayang is one of the KSPN, included as an additional focus on the 2015-2019 development as stated in Law number 50 of 2011 concerning Master Plan of the National Tourism. The establishment of priority destinations is still relatively new. The Tanjung Kelayang's destination still has some problems as the impact of uneven tourism development before. In 2014, Tanjung Kelayang could only attract 3,206 tourists, and the management of Tanjung Kelayang still did not exist, (Dokumen BPPD Pemkab Belitung, 2016: 16). It is unfortunate if the priority destinations in Indonesia still cannot invite foreign tourists and have no special management.

Even though the Tanjung Kelayangs tour has become a priority destination, it will not necessarily directly affect the increase in the number of foreign tourists. Moreover, there are still some problems that must be addressed immediately. The Deputy Secretariat of Tourism Destination and Industry Development, Ministry of Tourism also said that around $80 \%$ of the governments commitment greatly affected the 
Vol. 1 No. 2 September 2018

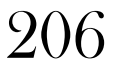

progress of tourism. Relations between the central and regional governments must be formed in the development of tourism as well as this relationship in the form of cooperation including through coordination, synchronization, commitment, and agreement. Therefore, researchers conducted a study titled "Government Cooperation: Cooperation between the Central and Regional Governments in the Development of Tourism Priority Destinations in Tanjung Kelayang, Bangka Belitung.”

\section{LITERATURE REVIEW}

Based on research conducted by Sapta Nirwandar in 2004, the title "Tourism Sector Development in the Era of Regional Autonomy" came from the Ministry of Tourism. The problem in this research is that the development of the tourism sector is only oriented to the western part of Indonesia while the Java-Bali region is the main concentration site of tourism development. The results are the central and regional government must espouse the program to open other foreign tourist entrances.

The relevance of the author's research is the discovery or outcome that can provide information about tourism conditions prior to the prioritization of tourism programs in 2016. This is also the reason for the formation of priority tourism with the number of 10 New Bali" because only one year before one entrance for foreign tourists. In the other words, it can answer previous research that suggests the central and regional governments to form other foreign tourist entrances.

Furthermore, in 2015, a study conducted by Yustisia Kristiana entitled "Improving the Role of the Central Government in Deconcentration and Assistance Tasks for the Development of Tourist Attraction at Provincial and District/ City Levels". In the study, it is expected that to accelerate the development of national tourism, the government also 
contributes to develop by establishing the division of tourism in Indonesia to classify and facilitate its development. The results in the form of the principles of tourism destination development in Indonesia include environmental sustainability, socio-cultural sustainability, economic sustainability, and institutional sustainability. Support is made in an effort to optimize the principle of deconcentration and co-administration in JOURNAL tourism development, consisting of: (1) communication, coordination and synchronization of programs; (2) preparation of joint indicators; and (3) monitoring and evaluation of futures. The results and findings on this previous research will be used as variables in the author's research in order that it is easier to analyze data.

There is also a study conducted by Budi Istiawan in 2014 entitled "Coordination and Cooperation between Central Governments and Regional Governments in Preservation of Cultural Heritage". The problem in the study is the lack of cultural heritage preservation as utilizing cultural heritage and values by the community. The findings are that the preservation of cultural heritage is no longer the domain of the central government, but also the domain of regional governments, hence the need for coordination, clear synchronization, and synergy of cultural preservation.

The relevance to this previous research is the results or findings in the form of the need for synchronization, coordination and synergy can be used as guidelines in the preparation of this research because in this study there are also coordination, commitment, synchronization, and agreement in the cooperation between the central and regional governments. With the existence of this previous research, it is very clear that in a collaboration between the central government and local government there must be clear coordination so that the objectives or targets can be achieved. 
Vol. 1 No. 2 September 2018

208

\section{THEORY REVIEW}

\section{Government Cooperation}

Based on government regulation in number 5 of 2008 concerning Deconcentration and Co-administration, deconcentration aims to realize harmonious relations between government structures and between regional governments. Likewise law number 23 of 2014 regarding Regional Government, there is no explicit prohibition on cooperation or mutual agreement between the central and regional governments in accelerating development, (d'Hotman de Villiers, 2015). In other words, in the government regulation and the act, there is a need for harmonious relations and cooperation between the central and regional governments.

The Republic of Indonesia is a unitary state with a decentralized system, (Kaho, Bayo, Parlindungan, \& Jamson, 2012). The complexity of the decentralization concept in general can be categorized into two perspectives namely political and administrative decentralization, (Hidayat, 2008). Laksono, Topatimasang and Permana said that "decentralization is a process where

central government transfer political, fiscal, and administrative power to lower levels in an administrative and territorial hierarchy", (AntwiBoasiako, 2010). Decentralization covers the process of political, financial and administrative transfers from the central government to local governments.

In addition (Dubois \& Fattore, 2009; Larson, 2000; $\underline{\text { Rondinelli \& Vastag, 2000), World Bank (1999), and (Crook, }}$ Crook, \& Manor, 1998) argue that decentralization is the transfer of authority and responsibility from the central government to the regions and deconcentration is part from administrative decentralization, (Hartanti, 2010). Thus deconcentration is administrative decentralization. The coordination of the deconcentration function is divided into three parts, (LAN, 2007: 18-20). 
a. Functional Integration

There are several coordination connected to functional integration namely planning, organizing, implementing and controlling. Then, there is the term of coordination of planning, coordination of implementation, and coordination of supervision.

b. Institutional Integration

Institution is also a factor that determines the success of the implementation of deconcentration and interrelated institutions with deconcentration functions including institutions at the central, provincial and district/city levels. The Minister/Leader is obliged to carry out technical or functional guidance on the device in the area. Furthermore, the governor determines which devices will be given the responsibility to carry out the delegated authority whether to the Secretariat, Regional Public Service (Dinas), Regional Technical Institutions (Lemtekda), Service Technical Implementation Unit (UPTD or the Central Apparatus in the area. The Governor also coordinates with agencies in the province as well as with the related district/city governments.

c. Program Integration

Program integration starts in the development process by integrating the planning function in which the central and regional governments determine the basic elements of planning both in the form of mission, vision, intentions, objectives, strategies and objectives. This element will be realized in the form of regional and sectoral programs and still pay attention to coordination.

\section{Tourism Destination Development}

One of the directions from President Jokowi is to form ten-national tourism destinations or called as "Priority Tourism Destinations". In the development of tourisma planisneeded 
Vol. 1 No. 2 September 2018 to reduce the economic, social and cultural impacts in society, especially in tourist destinations, (Muljadi, 2009). Thus, in the development of priority tourism destinations, Tanjung Kelyang must be guided by the principles of tourism development. The principle of developing tourism destinations in Indonesia includes, (Kristiana et al., 2015).

a. Environmentaly sustainable, is the development of national tourism destinations that are environmentally friendly and able to protect, protect and preserve natural wealth.

b. Social Culture Sustainable, is the development of tourism destinations that are able to maintain the quality and social values of local culture.

c. Economically Sustainable, is the development of national tourism destinations must be able to maintain sustainability and economic growth by providing business opportunities and employment.

d. Institutionaly Sustainable, is the development of tourism destinations must be able to develop institutional cooperation, creative, productive and mutually beneficial partnerships between the government and society.

\section{RESEARCH METHODS}

The method used in this research is qualitative method and descriptive type. Data collected, processed and analyzed are primary data and secondary data. Primary data comes from Deputy of Tourism Destination and Industry Development in the Ministry of Tourism, Culture and Tourism Office of the Province of Belitung Islands, Tourism Office of Belitung Regency, and Communities around Tanjung Kelayang Destinations, while secondary data comes from previous research, government reports, documents official, media, and other sources concerned with this research. The variables that will be analyzed are the model of cooperation between the 
central and regional governments in developing tourism priority destinations in Tanjung Kelayang and inhibiting and supporting factors in the cooperation between the central and regional governments in developing tourisms priority destinations in Tanjung Kelayang.

\section{DISCUSSION DAN RESULT}

\section{Model of Cooperation between the Central and Regional Governments in the Development of Tourism Priority Destinations in Tanjung Kelayang, Bangka Belitung}

Based on Law in number 50 of 2011 concerning Master Plan of the National Tourism Planning that the Tanjung Kelayang destination is one of the KSPN (National Tourism Strategic Areas) in Indonesia. The development of KSPN Tanjung Kelayang is managed through the delegation of deconcentration authority from the central government to the regional government. However, the development of research conducted found that tourism in Tanjung Kelayang is not only managed through the domain of devolution of deconcentration in the KSPN status, but the central government through the Ministry of Tourism gives more authority to the regional government to accelerate the development of tourism, namely by establishing and stipulating Tanjung Kelayang as special economic zone. In accelerating the development of Tanjung Kelayang tourism, the Ministry of Tourism has a concept called ABCGM (Academics, Business, Community, Government, Media).

Tanjung Kelayang Tourism which is managed both in the status of KSPN and KEK (Creative Economic Zone) has several differences both in the responsible actors, funding sources, coordination, and development fields built. However, both of these management still aim to achieve what is called another major gateway in Indonesia other than Bali. 
Vol. 1 No. 2 September 2018

Actors, in the development of KSPN Tanjung Kelayang, consist of the Ministry of Tourism as planner and delegation of deconcentration authority, Culture and Tourism Office of the Belitung Islands Province as program implementer and reporting through deconcentration funds and Belitung Regency Tourism Office as executor and reporting program through Special Allocation Funds (DAK) funds and/or grants. These actors work together through three integration, namely functional, program and institutional integration, (LAN, 2007: 18). With this deconcentration and coadministration support as a policy of regional autonomy and fiscal decentralization, it will support the achievement of national development goals and as a delegation of central authority in the regions in the form of equitable tourism development.

Based on the results of the research, the tourism sector that was built in the development of KSPN Tanjung Kelayang is only limited to the development of human resources/ industry and promotion/marketing, or more on the development of nonphysical activities. The authority owned by the Ministry of Tourism is that the government will allocate deconcentration funds to local governments, if the local government proposes activities that are in accordance with the criteria or menu as matters which can be proposed through deconcentration and DAK. If the local government cannot see the opportunity by proposing activities that are not in accordance with the criteria, the central government will not allocate the funds. This is in lies of the government's commitment to the development of tourism in the region.

Tanjung Kelayang's tourism determination as KEK Tanjung Kelayang is basically to support and encourage the acceleration for the development of Tanjung Kelayang KSPN. Actors who manage not only the Ministry of Tourism as an institution in the central government, but also managed by 
the Ministry of Public Works, Ministry of Energy and Mineral Resources, Ministry of Transportation and Coordinating Ministry, while institutions in the local government consist of the Culture and Tourism Office of Belitung Islands and Tourism Office of Belitung Regency and the Geopark Management Agency. The actors in the cooperative relation are no longer instructive, but the cooperative relations are participatory in nature where the role of the central government has diminished because the region has the authority of regional autonomy in the tourism affairs.

In the results of the research, the development of the KEK's Tanjung Kelayang is managed through four main points of coordination or collaboration.

a. Dissemination of destination development programs in the central and regional level;

b. Synchronization of programs and cross-sector development's activities of priority destinations, commitment and development;

c. Agreement of priority destinations;

d. Agreement of the implementation of the destination.

The tourism sector built in its development also has more coverage than in the development of KSPN Tanjung Kelayang, which includes 3A (Amenitas, Accessibility, Attractions), Marketing/Promotion (Branding, Advertising, Selling), and Human Resources/Industry. The authority possessed by the central government in developing this KEK is more on the development of Amenitas and Accessibility, the rest is mostly managed by the regional government while still coordinating among others.

Tourism Priority Destinations in Tanjung Kelayang is one of the destinations that will become a gateway for tourists to achieve tourism goals namely increasing GDP, foreign exchange and employment. However, tourism is not only 
Vol. 1 No. 2 September 2018

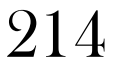

associated with an increase in GDP, regional government foreign exchange but it cannot be used as a benchmark in the success of tourism development. Tourism must also prioritize the sociocultural order and natural environment around these tourist destinations, if there is damage in this case tourism cannot be said to be successful. Tourism is only considered as a business sector that only seeks maximum profit for welfare for the actors who play a role.

We need to realize that in the previous statement that the central government, namely the Ministry of Tourism stated that "tourism is a contributor to GDP (Gross Domestic Product), foreign exchange and employment that is easy and cheap". If the government focuses on these goals, the wider interests of the nation can be harmed by short-term. This is the governments action to only strive increasing economic growth without regard to the occurrence of damage to the natural environment and social culture in society. The government in making the new program must really understand the purpose of building tourism for the good of Indonesia and its people in the long run, not just following the trend of what is "trending" in developed countries. Therefore, the principles of tourism development are needed in developing national tourism such as the development of Tanjung Kelayangs priority destinations both in terms of environmental, socio-cultural, economic and institutional sustainability.

The results also showed the destinations Tanjung Kelayang which were not all the authority or domain of the central government delegated administrative authority (deconcentration) to the regional government in the status of KSPN Tanjung Kelayang. However, it is not considered that regions only carry out and report programs and activities delegated by the center. Local governments also have the authority to propose what activities they want and will carry 
out in their regions, but are still in the realm of coordination. There are three functions of integration that can be seen in the delegation from Ministry of Tourism to the Office of Culture and Tourism of the Province of Bangka Belitung Islands and Tourism Office of the Regency of Belitung.

\section{Functional Integration}

The results show that functional integration in the development of Tanjung Kelayang's priority destinations still has problems when the coordination process of planning activities or programs in the Tourism Office of Belitung Regency has been prepared. But when it has been proposed to the Ministry of Tourism there is a change and not in accordance with what was planned. The Department of Tourism wants the development of the Tanjung Kelayangs destination more on promotion and marketing, but the proposed activities that support the promotion of the allocation of funds have no assistance. This is because the submission of proposal activities is not included in the physical activity menu list of the tourism ministry so that the proposed activities are not realized.

In addition, the planning and implementation coordinations are also a key to functional integrity. The coordination of the implementation on the development of KSPN Tanjung Kelayang has proceeded according to the target, but no activities have been funded through grants and transferred to DAK to the district. In the coordination of this implementation, it is found that the Department of Tourism in Belitung Regency could not see the opportunity in submitting activities through DAK, so that little could be done. Whereas for supervision coordination, the provincial government still has problems in coordination with the district because the UPT's provincial government has not been established in Belitung, the provincial government must travel long distances to the district to coordinate supervision. 
Vol. 1 No. 2 September 2018

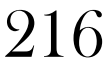

\section{Intitusional Integration}

Institutional integration is also a factor that greatly influences the successful implementation of the transfer of central authority to the regions. Based on the results of the analysis, the Ministry of Tourism delegates part of its authority to the Governor of Bangka Belitung Province in the development affairs of KSPN Tanjung Kelayang. Furthermore, the Governor determines the regional apparatus that will be given the responsibility to carry out the authority. The instrument of this area is the Culture and Tourism Office of Bangka Belitung Province and Tourism Office of Belitung Regency.

The results of the study found that coordination between the provincial government and the district government had to be done, but the provincial government did not allocate budget and state revenues $(\mathrm{ABPN})$ to the district government so that there was no cooperation and coordination relationship. On the other hand, district governments often coordinate directly with the central government. In fact, institutional integration concerns deconcentration functions at the central, provincial and district levels, but in institutional integration, between provinces and districts is not formed.

\section{Program Integration}

The development of KSPN Tanjung Kelayang is more domains in non-physical programs such as human resources development and promotion/marketing through deconcentration funds to the province, while physical programs such as developing amenitas through DAK funds to the District. During this time, the integration of the program in the deconcentration function was only in the promotion or marketing development, not much human resource and industrial development. Additionally, none of the deconcentration funds allocated to the provinces are included in the $3 \mathrm{~A}$ development fields such as amenities, accessibility, and 
attractions. This is unfortunate that Tanjung Kelayang is a still very minimal and non-existent.

Based on the data found that only three activities funded by DAK such as the construction of culinary snacks centers, installation of garden lights, and the construction of dive centers, whereas in the menu of the DAK physical activity from the Ministry of Tourism, there are eighteen activities that can be submitted by area. It is very unfortunate the district government cannot take advantage of these opportunities. They should be able to see opportunities through submitting activities included in the Ministry of Tourism, because it can improve in the development of tourism destinations in Belitung Regency, especially Tanjung Kelayang which is designated as a priority destination.

Thus, it can be said that the development of KSPN Tanjung Kelayang is still considered to be very lacking. In the research process conducted, researchers found several important things that were not previously formulated in the research objectives. The researchers found that in the development of the Tanjung Kelayangs destination and it was also developed in the status of KEK Tanjung Kelayang. It is as in government regulations in number 6 of 2016 concerning Special Economic Zone in Tanjung Kelayang. The collaboration between the central, provincial and district governments, the Ministry of Tourism is illustrated through the holding of the National Coordination Meeting which is held 4 times in 2017 namely:

1. The $1^{\text {st }}$ National Coordination Meeting, on September 30-31, 2017

2. The $2^{\text {nd }}$ National Coordination Meeting, on May 1819, 2017 
Vol. 1 No. 2 September 2018

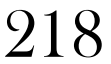

3. The $3^{\text {rd }}$ National Coordination Meeting, on September $26-27,2017$

4. The $4^{\text {th }}$ National Coordination Meeting, on 6-7 December, 2017

Previously, if the KSPN's Tanjung Kelayang only developed the tourism sector in the HR and industry, marketing and promotion sub-sectors, then in the development of KEK Tanjung Kelayang there were new sub-fields that were not included in the KSPN's Tanjung Kelayang development, this sub-field included 3A (Accessibility, Amenitas, Attractions), Marketing and Promotion (Branding, Selling, Advertising), Human Resources and Industry (Society, Human Resource and Industrial Business).

For four points of coordination and cooperation between the central and regional governments, it was found that cooperation and coordination between Department of Culture and Tourism for Bangka Belitung and Tourism Office of Belitung were still lacking. The problem of lack of coordination between the government resulted in several programs and activities as the Tanjung Kelayang's Destination Development Action Agreement, especially in the field of promotion and marketing development that was not appropriate and not planned activities such as Sungailiat Triathlon, Laskar Pelangi Festival, Toboali City On Fire, and Bangka EXPO. Besides that, it can be said that the provincial government prioritizes tourism promotion and marketing on Bangka Island, not in Belitung.

However, the development of KEK Tanjung Kelayang in 2017 prioritizes the accessibility and amenities, which is a good progress for the development of the Tanjung Kelayang destination, because prior to the establishment of KEK Tanjung Kelayang and the status of KSPN Tanjung Kelayang, accessibility and amenities still does not become a priority program. 
5. Inhibiting and Supporting Factors in the Cooperation between the Central and Regional Governments in the Development of Tourism Priority Destinations in Tanjung Kelayang, Bangka Belitung

The Tanjung Kelayang's destination developed by the government is inseparable from the presence of both inhibiting and supporting factors. This factor greatly influences the government's tips in developing tourism. The inhibiting factors found by researchers are lack of accessibility, especially transportation, lack of awareness of community tourism and lack of community creativity. The supporting factors found are the number of foreign tourists and there are already famous tourist attractions.

The results showed that the inhibiting factors of lack of accessibility especially transportation indicated the difficulty of tourists or visitors to go to Tanjung Kelayang destinations because the government did not provide public transportation so tourists must have private transportation. In addition, another inhibiting factor is the lack of awareness of the community's tourism shown that there is still a lot of garbage and the public is less concerned about the preservation of the surrounding environment, and the inhibiting factors of lack of creativity of the community shown by the community cannot highlight regional characteristics such as culinary characteristics, handicrafts, and community production as well as one gallery that sells the product in Belitung.

In addition to the inhibiting factors, there are supporting factors in the development of Tanjung Kelayang destinations, namely the number of foreign tourists coming to Tanjung Kelayang destinations which increased by $22.65 \%$ from 2016 and the presence of already famous tourist attractions such as Tanjung Tinggi tours or "Laskar Pelangi Island". Its existence is very close to the main tourist attractions of Tanjung Kelayang. 
Vol. 1 No. 2 September 2018
Previously it was explained that tourism is not only limited to improving the economy of the community but also must prioritize damage to the natural environment and social culture in the community. By looking at the supporting and inhibiting factors in the development of Tanjung Kelayangs priority destinations, optimizing the development must refer to the principles of developing tourism destinations in Indonesia including, (Kristiana et al., 2015):

\section{a. Environmentally Sustainable}

By looking at the environmental conditions in Tanjung Kelayangs tourism destinations, the environmental conditions are still said to be bad because there are a lot of plastic waste and other trash that pollutes the beach, as well as the many irregular small huts so the beach looks shabby. The circumstances like that, the government still has not succeeded in socializing tourism awareness to the community, and has not succeeded in training and fostering Community Human Resources (Pokdarwis).

In addition to that, Tanjung Kelayang also has the arrival of Cruise Ships which bring tourists from Australia on the "Sail Indonesia" event. This activity is very supportive in the development of Tanjung Kelayang tourism either promotion or marketing, but we saw from the other side that the cruise ship could damage wealth underwater or underwater ecosystem. Therefore, in order to optimize the sustainability of this environment, the government must bring more community roles to be able to preserve tourism and care more about the cleanliness of the coastal environment, funds run activities that not only support from one side only.

\section{b. Socially Culture Sustainable}

One of the successes of tourism is not only seen from the sustainability of the tourism environment, but also the social and cultural sustainability of the community. 
The large number of foreign tourists who come to travel, there are many social cultural values that they bring to Indonesia. Their cultures are clearly not the same as the Indonesian people. The existence of their culture that enters the community, there will be a tendency towards discomfort towards the culture or the tendency of the community to accept the culture while still being accepted by the social culture of the surrounding community.

Based on the results of the field survey, bringing the public to accept the arrival of foreign tourists well, there was no indication of the discomfort of the surrounding community with the social behavior of foreign tourists. On one side the community is very friendly with visitors coming. Likewise, too, foreign tourists are very friendly with the surrounding community, which shows the interaction among them.

c. Economically Sustainable

One of the goals of tourism is to improve the economy of the community through employment opportunities. With the existence of this national tourism, the needs of tourists will also increase such as food needs, lodging and a comfortable recreation area. These needs cause the government and the community to be able to fulfill it, so to meet these needs people open small businesses such as restaurants, restaurants, or hotels. Whereas the government $\mathrm{i}$ tself has made homestay and hotel development programs for the fulfillment of tourist lodging, the homestay and the hotel will later absorb and need the workforce of the surrounding community, as well as restaurants that require a lot of workforce. In addition, the government also programs raw water for quality fulfillment and this is very supportive in meeting the needs of tourists in the form of clean water. In tourism, tourists are also needed services when traveling such as 
Vol. 1 No. 2 information services and tour guides. In fact these needs will open opportunities for people to work.

However, based on the results of the survey to the field, the people in Belitung have indeed opened small businesses to meet the needs of tourists, but these efforts are more likely to less a highlight what is characteristic of the region. In this area, there is only one place or business that really emphasizes Belitung's distinctive features. On the other hand, the government can open jobs through the construction of homestays and hotels. But, it must also foster community groups to be able to better show what is characteristic of the Belitung.

\section{d. Institutionally Sustainable}

Previously the Tanjung Kelayang's destination is only the status of the KSPN, where institutional sustainability is only deconcentrated as the government delegated deconcentration authority to the provinces and the province as executor and reporting of programs that had been carried out. Relationships and sustainability are only limited to relationships that are instructive. The central government is more dominant than the independence of local governments.

However, with the rapid development of tourism and assessed as a priority development sector, the Tanjung Kelayang's destination is also designated as KEK. The development of the KEK Tanjung Kelayang is considered participatory as this is because the Ministry of Tourism has cooperated with other ministries and the local government. However, the results of the study found that the collaboration between the provincial and regional government is still not established, as indicated by the existence of several programs that are not in accordance with the supporters of the KEK Tanjung Kelayangs development. 
Based on the explanation and description above, the researcher can find a model of cooperation between the central and regional governments in developing tourism priority destinations in Tanjung Kelayang, as follows:

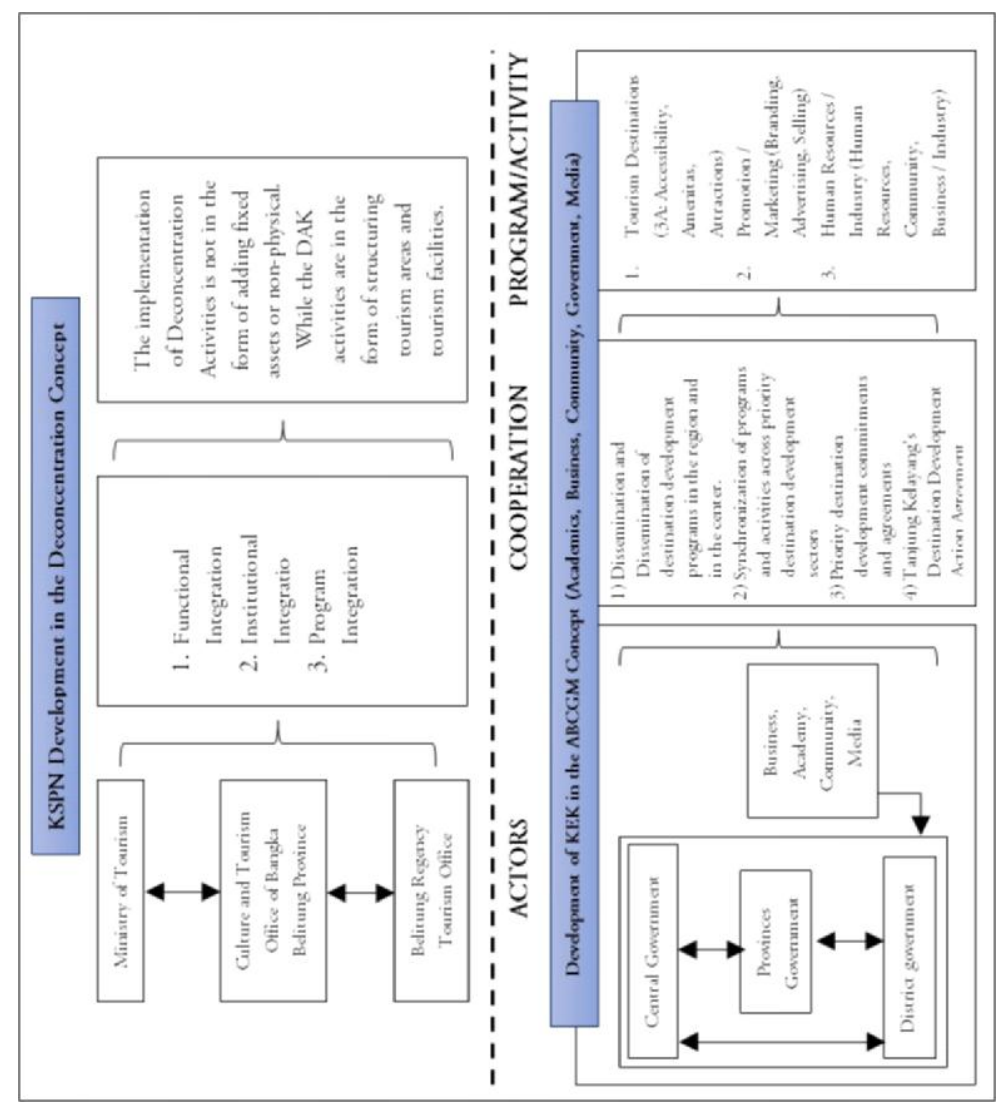

Source: processed from various sources by researchers

\section{CONCLUSION}

The cooperation between the central and regional governments is not enough to make the Tanjung Kelayangs destinations to be "Priority Destinations or New Bali" in Indonesia. It is affected because there are still problems in both development in the status of KSPN or KEK and problems from the tourism side itself. The problem of cooperation 
Vol. 1 No. 2 September 2018 between the central and regional governments in the development of Tanjung Kelayangs priority destinations must be further confirmed how their progress comes from the cooperation in Tourism Priority Destination Development in Tanjung Kelayang that can be created and lead to the direction of the President: "Ensure Progress in the 10 Destinations National Tourism."

\section{REFERENCES}

Antariksa, B. (2015). Kebijakan pembangunan kepariwisataan: pengembangan kepariwisataan yang berkelanjutan dan perlindungan kekayaan intelektual: Intrans Publishing.

Antwi-Boasiako, K. B. (2010). Public administration: Local government and decentralization in Ghana. Journal of African Studies and development, 2(7), 166-175.

Crook, R. C., Crook, R. C., \& Manor, J. (1998). Democracy and decentralisation in South Asia and West Africa: Participation, accountability and performance: Cambridge University Press.

d'Hotman de Villiers, J. (2015). The perception, knowledge and utilisation of research and its role in the chiropractic profession as determined by chiropractors attending the World Federation of Chiropractic biennial conference 2013.

Dubois, H. F., \& Fattore, G. (2009). Definitions and typologies in public administration research: the case of decentralization. Intl Journal of Public Administration, 32(8), 704-727.

Hartanti, E. (2010). Dekonsentrasi di Indonesia. Jurnal Alokasi Dana. FE, UI, 36-63.

Hidayat, S. (2008). Desentralisasi Dan Otonomi Daerah Dalam Perspektif State-Society Relation. Jurnal Poelitik, 1(1).

Kaho, J. R., Bayo, L. N., Parlindungan, U., \& Jamson, U. N. E. (2012). Analisis hubungan pemerintah pusat dan daerah di Indonesia: Center for Politics and Government (PolGov), Fisipol UGM.

Kristiana, I., McDonald, S., Tan, J., Joll, C., \& Heitz, A. (2015). Analysis of halogen-specific TOX revisited: method improvement and application. Talanta, 139, 104-110. 
Larson, R. (2000). Temporal modification in nominals. Handout of paper presented at the International Round Table "The Syntax of Tense and Aspect" Paris, France.

Moerwanto, A. S. (2017). Temporal Lag Effects of Alluvial System Under Unsteady Flow Conditions. Jurnal Teknik Hidraulik, 1(1), 1-16.

Muljadi, A. (2009). Kepariwisataan dan perjalanan: Rajawali Press.

Nirwandar, S. (2007). Pembangunan Sektor Pariwisata di Era Otonomi Daerah. Diakses pada, 24.

Ramadhani, B., Sulistyaningsih, T., \& Hadi, K. (2018). Government Cooperation: Kerjasama Pemerintah Pusat Dan Daerah Dalam Pengembangan Destinasi Prioritas Pariwisata Di Tanjung Kelayang, Bangka Belitung. LOGOS (Journal of Local Government Issues).

Ratman, N. (1976). Geological map of the Tolitoli quadrangle, North Sulawesi, Scale 1: 250000 (Quadrangles 2016-21172117). Geological Survey of Indonesia.

Rondinelli, D., \& Vastag, G. (2000). Panacea, common sense, or just a label?: The value of ISO 14001 environmental management systems. European Management Journal, 18(5), 499-510.

Saiman, L., Maykowski, P., Murray, M., Cohen, B., Neu, N., Jia, H., . . . Alba, L. (2017). Incidence, risks, and types of infections in pediatric long-term care facilities. JAMA pediatrics, $171(9), 872-878$. 